\title{
$\mathrm{NaOH}$ 처리시 Poly(ethylene terephthalate)필름의 표면특성에 영향을 주는 Diamine의 첨가효과
}

\author{
강인숙 ${ }^{\dagger}$ 배현숙
}

창원대학교 의류학과

\section{Effect of Diamine Addition in NaOH Treatment Solution on Surface Characteristics of Poly (Ethylene Terephthalate) Film}

\author{
In-Sook Kang ${ }^{\dagger}$ and Hyun-Sook Bae \\ Dept. of Clothing \& Textiles, Changwon National University; Changwon, Korea
}

\begin{abstract}
This study is a preliminary investigation of the influence of surface characteristics of substrates on detergency of particulate soil. The surface of PET film was modified with $\mathrm{NaOH}$ and $\mathrm{NaOH}+$ ethylene diamine on different times. The surface morphology of the film was scanned by AFM and surface energies were calculated from measured contact angles between several solutions and film based on the geometric mean and a Lewis acid base method. The surface morphology of PET film treated with $\mathrm{NaOH}$ and $\mathrm{NaOH}+$ ethylene diamine became more etched, and the surface area, surface roughness and the coefficient of friction of film increased with treatment of $\mathrm{NaOH}$ and $\mathrm{NaOH}+$ ethylene diamine. The contact angle of film treated with $\mathrm{NaOH}$ and $\mathrm{NaOH}$ + ethylene diamine decreased in water and surfactant solution; in addition, the surface energy increased was largely attributed to the increased portion on the polar surface energy of film. However, the effect of the diamine addition to the $\mathrm{NaOH}$ treatment solution on surface characteristics of PET film was insignificant.

Key words: $\mathrm{PET}$ film(PET 필름), $\mathrm{NaOH}$ treatment( $\mathrm{NaOH}$ 처리), diamine addition(디아민 첨가), surface characteristics(표 면특성)
\end{abstract}

\begin{abstract}
1. 서
론

기질의 표면특성이 고형오구의 세척성에 미치는 요인은 기 질의 표면형상과 접촉각, 표면에너지와 같은 표면활성으로, 이 러한 요인들은 오구가 기질의 부착과 탈락 정도를 예측할 수 있는 좋은 지표이다. 기질의 표면형상으로서의 미세구조는 표 면요철 정도, 돌기깊이와 넓이, 체적대비 표면적비와 표면거칠 기 등으로 고형오구의 세척성에 깊이 관여한다(Brendan, 1996; Tagawa \& Gotoh, 2007; Zimoch et al., 2002). 표면활성으로 서의 표면에너지는 두 물질이 접촉하면 형성되는 에너지로, 직 접 측정하는 것이 용이하지 않으므로 기질과 기질, 기질과 입 자간의 부착일을 고찰함으로 간접적으로 그 값을 유추한다(Rha et al., 2006). 일반적으로 표면에너지가 낮으면 두 물질간의 부 착력은 감소하고, 물질의 제거력은 증가한다. 이와 같이 표면에 너지가 두 물질간의 응착력에 영향을 주는 중요 요인으로 작용 하기 때문에 기질과 오구간의 응착력에 많은 영향을 받는 기질 과 입자오구의 부착과 제거거동에도 기질의 표면에너지가 영향
\end{abstract}

$\dagger$ Corresponding author; In-Sook Kang

Tel. +82-55-213-3491, Fax. +82-55-213-3490

E-mail: kangis@changwon.ac.kr
을 줄 것으로 생각된다. 기질의 표면형태 및 표면에너지는 고 형오구의 세척성을 좌우하는 직접적인 요인이 될 수도 있지만 계면활성제의 흡착량, 계면전기적 측면에서 기질의 $\zeta$ potential, 오구-오구 또는 기질-오구 상호작용에너지, 기질의 침윤성 등과 같은 세척환경에도 간접적인 영향을 줄 것으로 예상된다 (Hauthal, 2002; Kang \& Kim, 2001; Kang \& Jung, 2005; Mun \& Kang, 2009).

아민은 PET의 표면 친수화, 염색성 개선, 유연 효과 등의 목적으로 섬유개질에 이용되는 약품으로 섬유의 하전저하와 팽 윤현상을 증진시켜 $\mathrm{OH}$ 기의 섬유접근이 용이하여 가수분해를 촉진시키고(Lee \& Ryu, 1992), 그리고 섬유표면에 stress cracking을 발생시키기 때문에 PET의 표면형상 개질에도 사용 된다. Poly(ethylene terephthalate)는 구조가 치밀하지만 수산화 나트름을 처리하면 기질 표면에서 가수분해가 순차적으로 진행 되어 표면의 요철이 증가하는데(Haghighatkish \& Yousefi, 1992), 이때 아민을 첨가하면 기질의 식각정도와 형태의 변화 폭을 넓혀 표면 모폴로지의 다양성을 얻을 수 있다.

따라서 본 연구는 Poly(ethylene terephthalate)필름을 수산화 나트륨으로 처리할 때 아민의 첨가농도와 처리시간을 달리하여 기질의 표면 모폴로지에 변화를 주어 고형오구의 세척성에 영 
향을 주는 주요 요인인 기질의 표면특성을 고찰하였다. 기질의 표면특성으로 검토된 특성은 표면의 요철정도 및 형상, 그리고 마찰계수, 표면거칠기, 표면적을 검토하였으며, 표면활성으로 접 촉각과 표면에너지를 구하였다. 이 연구는 기질의 표면 미세구 조 및 표면활성이 고형오구입자의 섬유기질에서의 부착력과 제 거력에 미치는 영향을 고찰하기 위한 예비적 성격의 검토내용 이기 때문에 우선적으로 기질의 표면 형태를 다양화하고, 표면 에너지의 변화를 줄 수 있는 여러 가지 방법을 모색하였다. 먼 저 기질의 표면형태에 영향을 줄 수 있는 직조 효과를 배제하 기 위하여 섬유직물을 필름으로 대체 하였다.

\section{2. 실 험}

\section{1. 시료 및 시약}

시료는 두께 $75 \mu \mathrm{m}$ 의 PET필름으로 첨가물이 없는 순수한 것으로 Kolon사에서 제공받아 사용하였다. sodium hydroxide, ethylene diamine, sodium dodecylbenzene sulfonate(DBS) 등 의 시약은 1 급 이상을 사용하였고, 실험에 사용된 물은 증류수 를 이온교환수지로 탈 이온화하여 사용하였다.

\section{2. $\mathrm{PET}$ 필름의 $\mathrm{NaOH}$ 및 Diamine 혼합용액 처리}

액비 100 배의 $2.5 \% \mathrm{NaOH}$ 또는 $\mathrm{NaOH}+$ Diamine혼합용액에 $\mathrm{PET}$ 필름을 침지하여 $90^{\circ} \mathrm{C}$ 에서 처리시간에 변화를 주어 처리한 다음, 미 반응 시약은 $0.2 \%$ 세제액으로 $40^{\circ} \mathrm{C}$ 에서 10 분간 처리 하여 제거한 후 충분히 수세하고 자연건조 하였다.

\section{3. 표면특성}

$\mathrm{AFM}$ (Atomic Force Microscope)분석: PET필름의 표면을 Veecod 3100 을 사용하여 시료의 표면형태를 분석하고, 표면적 과 표면거칠기를 측정하였다.

마찰계수: KES-FB4 표면마찰시험기(Kato Tech Co., Ltd. $\mathrm{Japan}$ )를 사용하여 $50 \mathrm{~g}$ 하중에서 $1 \mathrm{~mm} / \mathrm{sec}$.의 속도로 측정하여 평균 마찰계수를 구하였다.

접촉각: 표면 처리한 PET필름을 $2.5 \mathrm{~cm} \times 5 \mathrm{~cm}$ 로 자른 후 contact angle meter(Erma Inc. model G-1)를 사용하여 상온 에서 물과 $0.1 \%$ 계면활성제(DBS)용액 0.01 를 필름에 점적하여 표면에 액적을 형성시켜 1 분경과 후 5 회씩 측정하여 평균값을 구하였다.

표면에너지: 표면에너지는 sessile drop방식을 이용한 접촉각 측정 방법을 이용하였는데, 구체적 산출과정은 Geometrical mean법으로 극성성분 및 비극성성분을 산출하여 표면에너지를 구하였다. 극성성분 및 비극성성분과 접촉각과의 관계식(b)에서 $\gamma_{S}^{p}, \gamma_{S}^{d}$ 를 구하기 위해 표면에너지 값을 알고 있는 두 종류의 액체를 이용하여 접촉각을 측정하고 식(c), (d), (e)와 같이 연 립방정식을 풀었다(Rha et al., 2006).

$$
W_{S L}=2 \sqrt{\gamma_{L}^{p} \gamma_{s}^{p}}+2 \sqrt{\gamma_{L}^{d} \gamma_{s}^{d}}
$$

$$
\begin{aligned}
& \mathrm{W}_{\mathrm{SL}} \text { : 고체-액체의 부착일 } \\
& \frac{1}{2} \gamma_{L}(1+\cos \theta)=\sqrt{\gamma_{L}^{p} \gamma_{s}^{p}}+\sqrt{\gamma_{L}^{d} \gamma_{s}^{d}} \\
& D=\left|\begin{array}{ll}
\left(\gamma_{L}^{p}\right)_{j}^{1 / 2} & \left(\gamma_{L}^{p}\right)_{j}^{1 / 2} \\
\left(\gamma_{L}^{p}\right)_{K}^{1 / 2} & \left(\gamma_{L}^{p}\right)_{K}^{1 / 2}
\end{array}\right| \\
& \gamma_{s}^{d}=\left[\begin{array}{ll}
\left(W_{S L} / 2\right)_{j} & \left(\gamma_{L}^{p}\right)_{j}^{1 / 2} \\
\left(W_{S L} / 2\right)_{k} & \left(\gamma_{L}^{p}\right)_{k}^{1 / 2} \\
& \mathrm{D}
\end{array}\right]^{2} \\
& \gamma_{s}^{p}=\left[\begin{array}{ll}
\left(\gamma_{L}^{d}\right)_{j}^{1 / 2} & \left(W_{S L} / 2\right)_{j} \\
\left(\gamma_{L}^{d}\right)_{k}^{1 / 2} & \left(W_{S L} / 2\right)_{k}
\end{array}\right]^{2} \mathrm{D}
\end{aligned}
$$

$$
\begin{array}{ll}
\gamma_{S} \text { : 고체시료의 표면장력 } & \gamma_{L} \text { : 액체의 표면장력 } \\
\gamma_{S L} \text { : 고체-액체의 계면장력 } & \theta: \text { 접촉각 } \\
\gamma^{p}: \text { 극성성분의 표면장력 } & \gamma^{d} \text { : 비극성성분의 표면장력 }
\end{array}
$$

\section{3. 결과 및 고찰}

\subsection{PET필름의 표면 형상}

표면모폴로지는 고분자 표면의 침윤성에 대단히 중요한 요소 이다. Fig. 1은 2.5\% NaOH용액 및 $2.5 \% \mathrm{NaOH}+7.5 \%, 15 \%$ ethylene diamine 혼합용액에서 처리한 PET필름의 $2 \mu \mathrm{m} \times 2 \mu \mathrm{m}$ 크기 $\mathrm{AFM}$ 이미지와 그의 단면 분석 그림이다. (b)는 $2.5 \%$ $\mathrm{NaOH}$ 단독용액에서 30 분간 처리한 필름으로 미처리된 필름 (a)에 비하여 표면의 일부가 용해되어 돌기개수는 감소하고, 돌 기와 돌기간의 거리가 증가하였는데, 이는 표면의 식각이 상당 히 진행되었음을 보여주고 있다. 이러한 결과는 PET는 $\mathrm{NaOH}$ 용액에서 고온처리하면 $\mathrm{OH}^{-}$이온이 ester기를 공격하는 가수분해 가 일어나 가용성인 disodium terephthalate와 ethylene glycol이 생성되는 기질 표면의 일부 용해에 따라 표면요철이 심화되었기 때문이다. (c-e)는 $2.5 \% \mathrm{NaOH}+7.5 \%$ ethylene diamine 혼합 용액, (f-g)는 $2.5 \% \mathrm{NaOH}+15 \%$ ethylene diamine 혼합용액 에서 처리시간에 변화를 주어 처리한 PET필름 각각의 표면형 상이다. 단독 $\mathrm{NaOH}$ 용액과 $\mathrm{NaOH}$ 용액에 ethylene diamine를 $7.5 \%$ 와 $15 \%$ 로 각각 첨가하여 30 분간 처리한 결과인 (b), (c), (f)를 비교하였을 때 이들 간 표면형상에 큰 차이는 없었다. 그 러나 같은 용액조건에서 처리시간에 변화주어 처리한 필름의 표면형상에는 차이가 있었다. $2.5 \% \mathrm{NaOH}+7.5 \%$ ethylene diamine 혼합용액에서 처리된 필름(c-e)에 있어 120 분으로 처리 


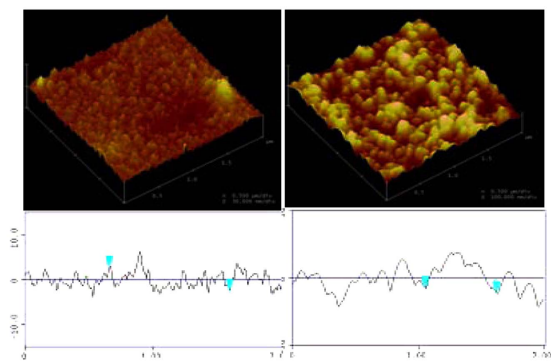

(a)

(b)
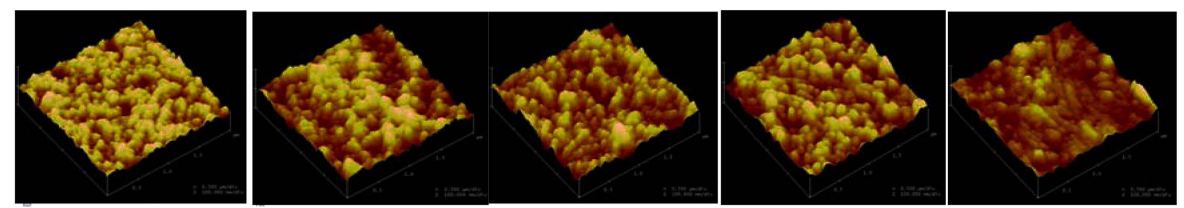

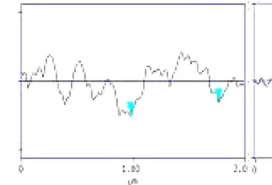

(c)

(d)

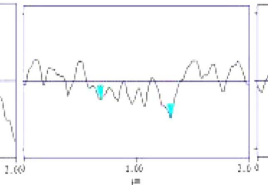

(e)

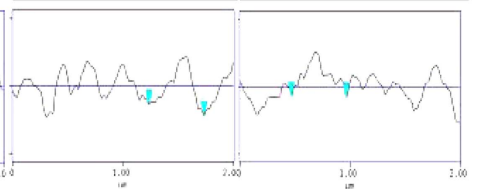

(f)

(g)

Fig. 1. AFM images and section analysis of PET films; (a) non-treated, (b) $2.5 \% \mathrm{NaOH}$, 30min., (c) $2.5 \% \mathrm{NaOH}+7.5 \%$ ethylene diamine, 30min., (d) $2.5 \% \mathrm{NaOH}+7.5 \%$ ethylene diamine, $60 \mathrm{~min}$., (e) $2.5 \% \mathrm{NaOH}+7.5 \%$ ethylene diamine, $120 \mathrm{~min}$., (f) $2.5 \% \mathrm{NaOH}+15 \%$ ethylene diamine, $30 \mathrm{~min}$, (g) $2.5 \% \mathrm{NaOH}+15 \%$ ethylene diamine, $60 \mathrm{~min}$..

된 필름에 비하여 60 분간 처리된 필름에서 돌기의 깊이가 보다 심화되었는데 이는 시간이 경과되면 식각되어 돌출된 부분이 식 각되어 표면형상의 요철이 감소하고 다시 식각되는 현상이 반복 적으로 일어나기 때문으로 생각된다. 이러한 현상은 $\mathrm{NaOH}+15 \%$ ethylene diamine 혼합용액으로 처리한 필름 (f, g)의 결과에서도 유사한 경향이 관찰된다.

Fig. 2는 $\mathrm{NaOH}$ 용액 및 $\mathrm{NaOH}$ 용액에 $7.5 \%$ 와 $15 \%$ 농도의 ethylene diamine 첨가한 혼합용액에서 처리시간에 변화를 주어 처리한 필름의 표면적을 검토한 결과이다. $\mathrm{PET}$ 필름을 $\mathrm{NaOH}$ 용액 및 $\mathrm{NaOH}$ 와 ethylene diamine 혼합용액에서 처리하면 필 름의 표면적은 다소 증가한다. 그러나 $\mathrm{NaOH}$ 용액에 첨가하는 ethylene diamine 효과는 크지 않았고 diamine의 농도가 증가 하면 표면적은 다소 감소하였다. $15 \%$ ethylene diamine이 첨 가된 경우 처리시간이 증가하면 다소 표면적이 감소하지만 $7.5 \%$ ethylene diamine이 첨가된 경우는 처리시간에 따른 변화 가 없었다. PET필름을 $\mathrm{NaOH}$ 용액 및 $\mathrm{NaOH}$ 와 ethylene diamine 혼합용액에서 처리하면 필름의 표면적이 다소 증가하 는 것은 작은 돌기개수는 감소하지만 필름의 표면이 식각되어 돌기의 둘레가 늘어나기 때문인데, 이는 Fig. 1의 (a)와 (b), (c)를 비교하면 예측될 수 있다.

PET필름의 표면상태를 나타내는 정량적 파라미터로서 표면 거칠기를 이용하기도 한다. Fig. 3 은 $\mathrm{NaOH}$ 용액 및 $\mathrm{NaOH}$ 용액 에 $7.5 \%$ 와 $15 \%$ 농도의 ethylene diamine을 첨가한 혼합용액에 서 처리시간에 변화를 주어 처리한 $\mathrm{PET}$ 필름을 $\mathrm{AFM탐침이} \mathrm{주}$ 사한 $2 \mu \mathrm{m} \times 2 \mu \mathrm{m}$ 면적의 표면거칠기를 나타낸 결과이다.

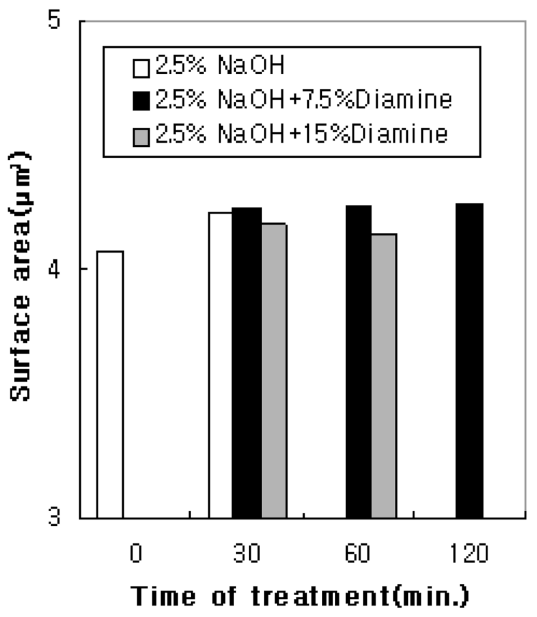

Fig. 2. The surface area of PET film treated with $\mathrm{NaOH}$ or $\mathrm{NaOH}+$ ethylene diamine.

$\mathrm{NaOH}$ 용액 및 $\mathrm{NaOH}$ 와 ethylene diamine혼합용액에서 필름을 처리하면 표면거칠기는 급격히 증가하지만, $\mathrm{NaOH}$ 용액에 첨가 한 ethylene diamine이 표면거칠기에 미치는 효과는 미미하다. 그리고 diamine의 첨가농도에 따라 처리시간이 표면거칠기에 미치는 효과에 차이가 있어, 처리시간을 30 분에서 60 분으로 증 가하면 $7.5 \%$ ethylene diamine 첨가농도에서 표면거칠기가 증 가하지만 $15 \%$ 첨가농도에서는 표면거칠기가 감소하였고, 표면 적과 마찰계수에 비하여 처리시간이 표면거칠기에 미치는 효과 는 상대적으로 컸다. 


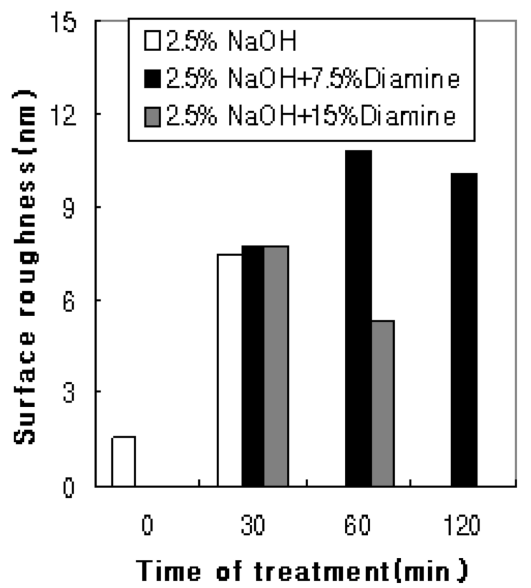

Fig. 3. The surface roughness of PET film treated with $\mathrm{NaOH}$ or $\mathrm{NaOH}$ +ethylene diamine.

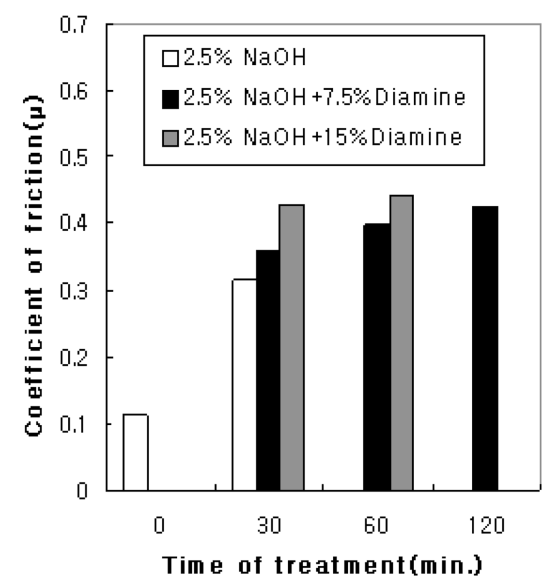

Fig. 4. The coefficient friction of PET film treated with $\mathrm{NaOH}$ or $\mathrm{NaOH}$ +ethylene diamine.

Fig. 4는 $\mathrm{NaOH}$ 용액 및 $\mathrm{NaOH}$ 와 ethylene diamine 혼합용 액에서 처리시간에 변화를 주어 처리한 PET필름의 마찰계수를 나타낸 결과이다. PET필름을 $\mathrm{NaOH}$ 용액 및 $\mathrm{NaOH}$ 와 ethylene diamine 혼합용액에서 처리하면 필름의 마찰계수는 급격히 증 가하는데 ethylene diamine처리농도가 높을수록 마찰계수의 증 가폭은 컸고 ethylene diamine 첨가농도에 관계없이 처리시간 이 증가하면 마찰계수도 증가하였다. 표면 모폴로지를 나타내 는 지표로서 $\mathrm{AFM}$ 이미지와 그의 단면 분석, 표면적, 표면 거 칠기, 마찰계수를 검토하였는데 이들 간 ethylene diamine처리 농도 및 처리시간에 따른 효과가 상이한데 이는 돌기의 개수, 돌기의 높이, 돌기와 돌기간의 거리에 따라 각 요인에 작용하 는 정도가 다르기 때문으로 생각된다. 표면거칠기, 마찰계수는 $\mathrm{NaOH}$ 용액 및 $\mathrm{NaOH}$ 와 ethylene diamine혼합용액의 처리농도 및 처리시간에 따른 효과에 차이가 상당히 있지만, 표면적은 차 이가 적은데, 이는 Fig. 1 의 미처리 필름 (a)에서 돌기의 깊이 는 크지 않지만 돌기의 개수가 많아 표면적이 유지되고, $\mathrm{NaOH}$
용액 및 $\mathrm{NaOH}$ 와 ethylene diamine혼합용액 처리 필름은 돌기 의 개수는 줄어들지만 돌기의 깊이 등이 증가하는 보완적 결과 를 가져오기 때문으로 생각된다.

\subsection{PET필름의 수용액의 접촉각}

고체 표면의 액체에 대한 침윤성은 액체 사이에 형성된 접 촉각에 영향을 받는다. 액체의 표면장력과 액체-고체간 계면장 력이 낮고, 고체의 표면장력이 크면 접촉각이 적어져서 액체는 고체표면을 잘 침윤하게 된다. 일반적으로 고체표면과 물의 접 촉각이 $90^{\circ}$ 미만이면 친수성 표면인데, 특히 접촉각이 $10^{\circ}$ 미만 이면 초친수성 표면이고, 접촉각이 $90^{\circ}$ 이상이면 소수성 표면, 접촉각이 $150^{\circ}$ 이상이고 기울임각이 $10^{\circ}$ 미만이면 초발수성 표면 이다.

$\mathrm{NaOH}$ 용액 및 $\mathrm{NaOH}$ 와 ethylene diamine 혼합용액에서 처 리시간에 변화를 주어 처리한 PET필름의 액체에 대한 침윤성 을 검토하기 위하여 순수 및 계면활성제용액에서 각각의 접촉 각을 측정한 결과는 Fig. 5 와 Fig. 6과 같다. 필름의 처리조건 에 따라 다소 차이가 있지만 계면활성제용액의 PET필름 접촉 각은 순수용액의 접촉각의 $20-40 \%$ 정도였다. 순수에 비하여 계 면활성제용액에서 $\mathrm{PET}$ 필름의 접촉각이 낮은 것은 물에 계면활 성제가 첨가되면 표면에 흡착 배열된 계면활성제 분자의 친수 기와 물분자 간에 인력이 작용하므로 표면의 물 분자가 안으로 끌리는 힘이 약해져 용액의 표면장력이 절반으로 저하되고 필 름과 수용액의 계면장력도 저하되어 접촉각이 감소되기 때문이 다. 미처리된 PET필름의 순수 및 계면활성제용액에서 접촉각 은 $73^{\circ}$ 와 $28^{\circ}$ 로 필름은 친수성 표면의 범주에 있다. 이 필름을 $\mathrm{NaOH}$ 용액 및 $\mathrm{NaOH}$ 와 ethylene diamine 혼합용액으로 처리하 면 순수 및 계면활성제용액에서의 접촉각은 감소하여 각 용액 에서의 접촉각은 $53^{\circ}-59^{\circ}$ 와 $8^{\circ}-14^{\circ}$ 정도였다. ethylene diamine 첨가가 순수 및 계면활성제용액에서 필름의 접촉각에 미치는 효과에 차이가 있어 $\mathrm{NaOH}$ 처리시 ethylene diamine를 첨가하

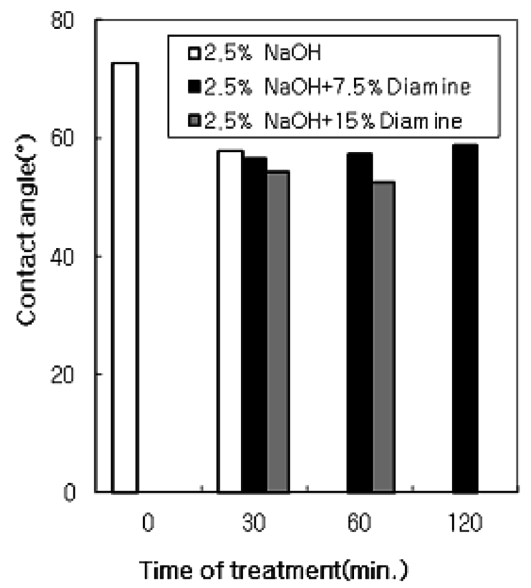

Fig. 5. The contact angle of water on PET film treated with $\mathrm{NaOH}$ or $\mathrm{NaOH}+$ ethylene diamine. 


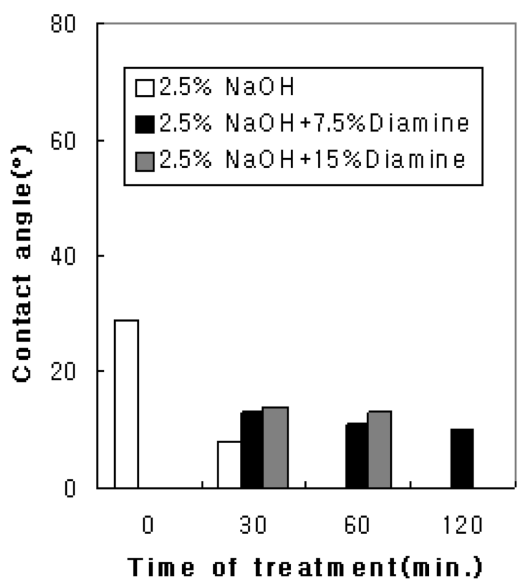

Fig. 6. The contact angle of surfactant solution on PET film treated with $\mathrm{NaOH}$ or $\mathrm{NaH}+$ ethylene diamine.

면 순수에서의 접촉각은 다소 감소하지만 계면활성제용액에서 의 접촉각이 다소 증가하였다. 그리고 ethylene diamine의 첨가 농도에 따른 처리시간 효과도 다른데, $7.5 \%$ ethylene diamine 첨가농도에선 처리시간이 증가하면 순수의 접촉각은 다소 증가 하지만 $15 \%$ ethylene diamine 첨가농도에선 접촉각은 다소 감 소하였다. ethylene diamine 첨가 되면 단독 $\mathrm{NaOH}$ 처리 필름에 비하여 계면활성제용액의 접촉각이 증가하고 ethylene diamine 첨가농도와 처리시간에 따른 경향이 순수용액에서의 접촉각과 차이가 있었다.

\subsection{PET 필름의 표면에너지}

접촉하는 두 물질의 각각의 표면에너지와 접촉한 후 형성되 는 계면에너지를 알면 두 물질 간의 부착력을 예측할 수 있다. 그러나 일반적으로 계면에너지를 측정하는 것이 용이하지 않으 므로 Dupre 식에 의한 부착력을 통해 그 값을 유추할 수 있으 나 본 연구 시료처럼 표면이 평활하지 않고 돌기가 있는 경우 에는 정확한 접촉면적을 알기 어렵기 때문에 일반식의 수정이 필요하다. 표면에너지를 구하기 위한 일반적인 방법은 sessile drop방식을 이용한 접촉각 측정이 기본이 되고, 구체적 산출과 정은 Geometrical mean법으로 극성 성분 및 비극성 성분을 산
Table 1. Surface tensions of solutions used to measure contact angles

\begin{tabular}{|c|c|c|c|}
\hline $\begin{array}{ll}\text { Solution } & \text { Surface tension }\end{array}$ & $\gamma_{\mathrm{Li}}$ & $\gamma_{L i}^{d}$ & $\gamma_{\mathrm{Li}}^{\mathrm{p}}$ \\
\hline Water & 72.8 & 21.8 & 51 \\
\hline Glycerol & 63.4 & 34 & 29.4 \\
\hline Bromnaphtalene & 44.4 & 44.4 & 0 \\
\hline Ethyleneglycol & 48.3 & 29 & 19.3 \\
\hline Formamide & 58.2 & 39 & 19.2 \\
\hline
\end{tabular}

출하여 표면에너지를 구하였는데, 용액에 따른 편차를 줄이기 위하여 극성과 비극성 성분의 고체 표면에 작용하는 힘의 양변 을 로 나눈 아래 식 $\sqrt{\gamma_{L i}^{d}}$ 으로 보정하였다.

$$
\frac{\gamma_{L i}(1+\cos \theta)}{2 \sqrt{\gamma_{L i}^{d}}}=\sqrt{\gamma_{S_{j}}^{p}} \frac{\sqrt{\gamma_{L i}^{p}}}{\sqrt{\gamma_{L i}^{d}}}+\sqrt{\gamma_{S_{j}}^{d}}
$$

$i:$ 용액의 종류, $j:$ 고체시편의 종류

표면에너지를 구하기 위하여 사용된 용액의 종류 및 방법은 표면에너지와 기질의 응착력에 관한 기존 연구(Rha et al., 2006)를 참조로 하였다.

Table 1는 측정에 사용된 용액의 표면장력 값이고, Table 2 은 $\mathrm{NaOH}$ 용액 및 $\mathrm{NaOH}$ 와 ethylene diamine 혼합용액에서 처 리한 PET필름의 각 용액에서의 표면장력 값이다. Table 2에 의하면 여러 가지 측정용액에서의 필름의 접촉각은 처리 조건 에 관계없이 대체적으로 물에서 높고, 브롬모 나프탈렌 용액에 서 가장 낮지만 PET 필름의 처리조건에 따른 필름의 접촉각은 용액의 종류에 따라 경향성에 다소 차이를 보이고 있다.

$\mathrm{NaOH}$ 용액 및 $\mathrm{NaOH}$ 와 ethylene diamine 혼합용액에서 $\mathrm{PET}$ 필름을 처리하면 대부분 측정 용액에서 필름의 접촉각은 감소하고, $\mathrm{NaOH}$ 용액에의 ethylene diamine첨가 효과는 적지만 $15 \%$ ethylene diamine첨가 농도에서 60 분간 처리한 필름의 물 에서의 접촉각은 $52.4^{0}$ 로 가장 낮았다. Table 1 의 각 용액의 표면장력과 Table 2 의 각 용액에서 측정된 필름의 접촉각을 Geometrical mean법에 근거를 둔 표면에너지 구하는 식에 대 입하여 각 용액조합의 표면장력과 접촉각에 의한 요인을 $\mathrm{Y}$ 축

Table 2. Contact angles of PET film treated with $\mathrm{NaOH}$ or $\mathrm{NaOH}+$ ethylene diamine for different time periods in various solution

\begin{tabular}{|c|c|c|c|c|c|c|}
\hline Sample & Solution & Water & Ethylene glycol & Bromonaph thalene & Formamide & Glycerol \\
\hline Non-treated & & 72.7 & 50.0 & 10.6 & 45.2 & 62.2 \\
\hline $2.5 \% \mathrm{NaOH}$ & $30 \mathrm{~min}$. & 57.7 & 30.9 & 10.1 & 41.6 & 57.6 \\
\hline \multirow{3}{*}{$2.5 \% \mathrm{NaOH}+7.5 \%$ Diamine } & $30 \mathrm{~min}$. & 56.5 & 26.0 & 8.8 & 35.1 & 59.1 \\
\hline & $60 \mathrm{~min}$. & 57.3 & 30.8 & 10.7 & 35.4 & 59.3 \\
\hline & $120 \mathrm{~min}$. & 58.7 & 28.1 & 10.1 & 34.6 & 60.2 \\
\hline \multirow{2}{*}{$2.5 \% \mathrm{NaOH}+15 \%$ Diamine } & $30 \mathrm{~min}$. & 54.3 & 20.9 & 7.0 & 30.2 & 64.9 \\
\hline & $60 \mathrm{~min}$ & 52.4 & 21.5 & 10.5 & 29.7 & 53.7 \\
\hline
\end{tabular}




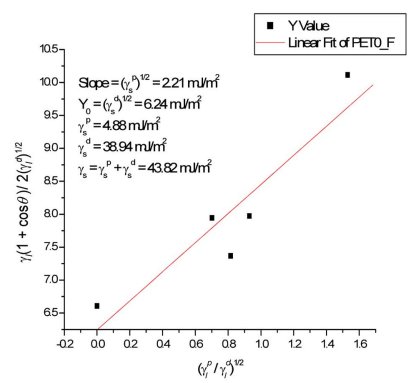

(a)

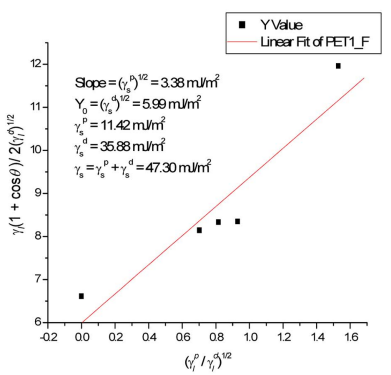

(b)

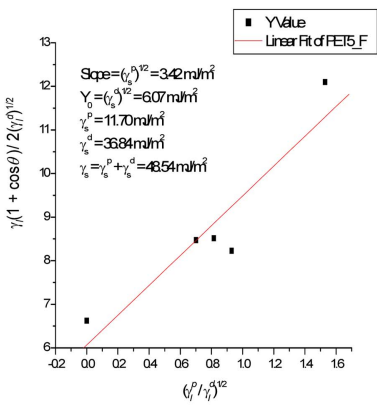

(c)

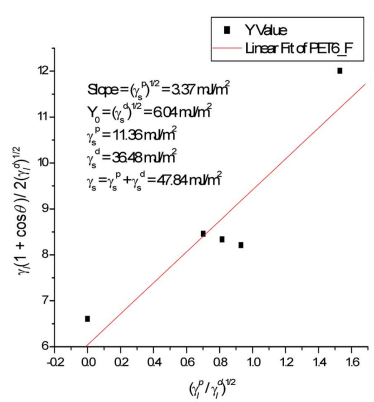

(d)

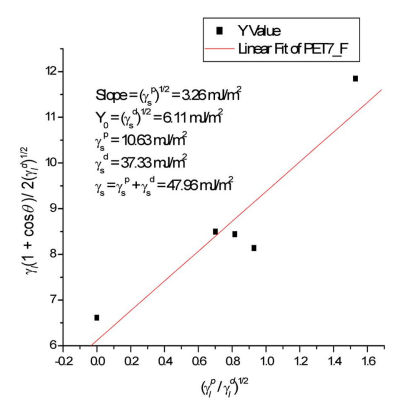

(e)

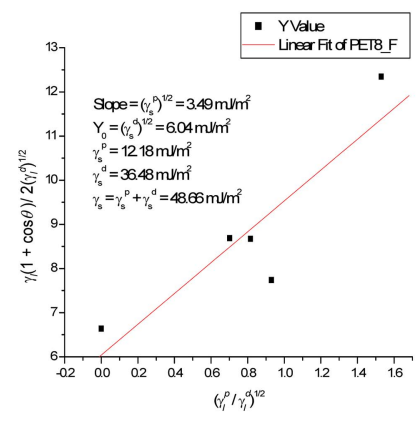

(f)

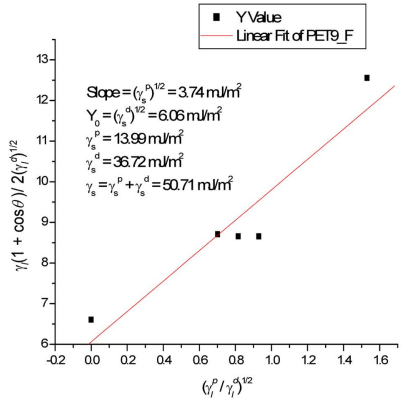

(g)

Fig. 7. Linear regression between solutions data and contact angles measured on PET treated with $\mathrm{NaOH}$ or $\mathrm{NaOH}+$ Diamine representing the polar(slope) and the dispersive (intersection of vertical axis) components of the surface tension; (a) non-treated, (b) $2.5 \% \mathrm{NaOH}, 30 \mathrm{~min}$., (c) $2.5 \%$ $\mathrm{NaOH}+7.5 \%$ ethylene diamine, 30min., (d) $2.5 \% \mathrm{NaOH}+7.5 \%$ ethylene diamine, $60 \mathrm{~min}$., (e) $2.5 \% \mathrm{NaOH}+7.5 \%$ ethylene diamine, $120 \mathrm{~min}$., (f) $2.5 \%$ $\mathrm{NaOH}+15 \%$ ethylene diamine, 30min, (g) $2.5 \% \mathrm{NaOH}+15 \%$ ethylene diamine, $60 \mathrm{~min}$. .

으로 하고, 용액의 극성 및 비극성 성분의 비에 대한 값의 제 곱근을 X축으로 하여 Linear regression fitting을 하여 Fig. 7 의 결과를 얻었다. 그리고 Fig. 7의 기울기와 $\mathrm{y}$ 절편을 통하여 $\mathrm{NaOH}$ 용액 및 $\mathrm{NaOH}$ 와 ethylene diamine 혼합용액에 처리한 PET필름의 극성성분의 표면장력 $\left(\gamma^{\mathrm{p}}\right)$ 과 비극성 성분의 표면장력 $\left(\gamma^{\mathrm{d}}\right)$ 을 분리하여 표면에너지를 구한 결과는 Table 3이고, 표면 에너지 총합 $(\gamma)$ 을 그림으로 나타낸 결과는 Fig. 8과 같다.

PET필름을 $\mathrm{NaOH}$ 용액으로 처리하면 극성 성분 $\left(\gamma^{\mathrm{p}}\right)$ 값은 증가 하고 비극성 성분 $\left(\gamma^{\mathrm{d}}\right)$ 은 감소하는데, 극성 성분의 증가폭이 비 극성 성분의 감소폭보다 많아 전 표면에너지는 증가한다. 여기 에 ethylene diamine를 첨가하여 $\mathrm{NaOH}$ 와 ethylene diamine 혼합용액으로 PET필름을 처리하면 단독 $\mathrm{NaOH}$ 용액에서 처리
한 필름에 비하여 ethylene diamine 혼합농도와 처리시간에 관 계없이 다소 극성 성분 $\left(\gamma^{\mathrm{p}}\right)$ 값과 비극성 성분 $\left(\gamma^{\mathrm{d}}\right)$ 값이 증가하여 전 표면에너지는 증가하였다. $\mathrm{NaOH}$ 용액 및 $\mathrm{NaOH}$ 와 ethylene diamine 혼합용액에 처리한 PET필름의 극성 성분의 표면장력 $\left(\gamma^{\mathrm{p}}\right)$ 이 증가하는 것은 PET필름의 가수분해에 따라 카 르복실기 및 수산기와 같은 극성기가 증가하고 아민처리에 따 른 친수기인 아미드기의 생성에 기인하는 것으로 생각된다. ethylene diamine 혼합농도와 처리시간에 따라 다소 차이가 있 지만 처리시간과 ethylene diamine 혼합농도가 극성 성분 $\left(\gamma^{\mathrm{p}}\right)$ 값 과 비극성 성분 $\left(\gamma^{\mathrm{d}}\right)$ 값에 미치는 영향은 크지 않지만 전 표면에 너지는 ethylene diamine의 첨가농도가 $15 \%$ 이고 처리시간이 60 분인 경우 가장 높았다. 
Table 3. Calculated surface energy of PET film treated with $\mathrm{NaOH}$ or $\mathrm{NaOH}+$ Diamine according to geometric mean method.

\begin{tabular}{ccccc}
\hline Smple & Energy & $\gamma^{\mathrm{d}}$ & $\gamma^{\mathrm{p}}$ & $\gamma$ \\
\hline Untreated & & 38.94 & 4.88 & 43.82 \\
\hline $2.5 \% \mathrm{NaOH}$ & $30 \mathrm{~min}$. & 35.88 & 11.42 & 47.30 \\
\hline $2.5 \% \mathrm{NaOH}+$ & $30 \mathrm{~min}$. & 36.84 & 11.70 & 48.54 \\
$7.5 \% \mathrm{amine}$ & $60 \mathrm{~min}$. & 36.48 & 11.36 & 47.84 \\
& 120min. & 37.33 & 10.63 & 47.96 \\
\hline $2.5 \% \mathrm{NaOH}+$ & $30 \mathrm{~min}$. & 36.48 & 12.18 & 48.66 \\
$15 \% \mathrm{amine}$ & 60min. & 36.72 & 13.99 & 50.71 \\
\hline
\end{tabular}

\section{4. 결 론}

$\mathrm{NaOH}$ 및 $\mathrm{NaOH}$ 와 ethylene diamine 혼합용액에서 처리한 PET필름의 표면형태 및 표면특성을 고찰한 결과 다음과 같은 결론을 얻었다.

1. $\mathrm{PET}$ 필름을 $\mathrm{NaOH}$ 및 $\mathrm{NaOH}$ 와 ethylene diamine 혼합용 액으로 처리하면 필름 표면의 식각현상이 진행되고, 표면 식각 정도는 ethylene diamine 첨가농도보다 처리시간에 영향을 받 았다.

2. $\mathrm{PET}$ 필름을 $\mathrm{NaOH}$ 용액 및 $\mathrm{NaOH}$ 와 ethylene diamine 혼 합용액에서 처리하면 필름 표면적의 증가폭은 낮지만, 표면거 칠기와 마찰계수의 증가폭은 높았다. 그러나 이들 특성에 영향 을 주는 ethylene diamine 첨가효과는 크지 않았다.

3. $\mathrm{NaOH}$ 용액 및 $\mathrm{NaOH}$ 와 ethylene diamine 혼합용액으로 처리하면 순수 및 계면활 성제용액에서의 접촉각은 감소하는데, 순수에 비하여 계면활성제 용액에서 접촉각의 감소폭도 컸고, ethylene diamine 첨가효과는 많았다.

4. $\mathrm{PET}$ 필름을 $\mathrm{NaOH}$ 용액 및 $\mathrm{NaOH}$ 으로 처리하면 극성성 분 $\left(\gamma^{\mathrm{p}}\right)$ 값은 증가하고 비극성성분 $\left(\gamma^{\mathrm{d}}\right)$ 은 감소하는데, 극성성분의 증가폭이 비극성성분의 감소폭보다 많아 전표면에너지는 증가하 지만, 표면에너지에 영향을 주는 $\mathrm{NaOH}$ 에의 ethylene diamine첨 가 효과는 낮았다.

\section{감사의 글}

본 논문은 2011-2012년도 창원대학교 연구비에 의하여 연구
되었음.

\section{References}

Brendan, C. (1996). The direct study of soil removal from solid substrates in detergency. Colloid and Surfaces A:Physicochemical and Engineering Aspects, 114, 161-164.

Haghighatkish, M., \& Yousefi, M. (1992). Alkaline hydrolysis of polyester fibers -structural effects. Iranian Journal of Polymer Science \& Technology, 1(2), 56-61.

Hauthal, H. G. (2002). Structured surfaces-detergency angled at new materials. Seifen Oele Fette Waches Journal, 128(10), 4-13.

Kang, I. S., \& Kim, B. J. (2001). Effect of electrolyte on the adhesion of particulate soil to fabric in the surfactant solution. Journal of the Korean Society of Clothing and Textiles, 25(8), 1465-1474.

Kang, I. S., \& Jung, S. Y. (2005). Effect of steric stability by adsorption of surfactant on the detergency of particulate soil in anionic/nonionic surfactant mixed solution(I). Textile Science and Engineering, 42(3), 166-173.

Lee, J. S., \& Ryu, H. S. (1992). An addition effect of amine and cethyl trimethyl ammonium bromide on alkali-treatment of polyester. Journal of the Korean Society of Clothing and Textiles, 16(3), 335344.

Mun, M. H., \& Kang, I. S. (2009). Interfacial electrical effect of particle radius on detergency of particulate soil- particle sizes and dispersion stability of particle-. Textile Science and Engineering, 46(6), 334-341.

Rha, J. J., Kwon, S. C., \& Jeong, Y. S. (2006). The effects of surface energy and roughness on adhesion force. The Korean Society of Mechanical Engineers, 30(11), 1335-1347.

Tagawa, Y., \& Gotoh, K. (2007). Effect of surface free energies on the detergency phenomena of particulate soils. Journal of the Japan Research Association for Textile End-Uses, 48(6), 29-36.

Zimoch, J., Hreczuch, W., Trathnigg, B., Meissner, J., Bialowas, E., \& Szymanowski, J. (2002). Detergency and dynamic surface tension reduction of oxyethylated fatty acid methyl esters. Tenside Surface Detergents, 39(2), 8-16.

(Received 28 November 2012; 1st Revised 12 January 2013; 2nd Revised 21 January 2013; Accepted 15 March 2013)

Copyright $(C$ The Society of Fashion and Textile Industry. 2013. This is an open access article distributed under the terms and conditions of the Creative Commons Attribution Non-Commercial license (http://creativecommons.org/licenses/by-nc/3.0/), which permits unrestricted non-commercial use, distribution, and reproduction in any medium, provided the original work is properly cited. 